\title{
PUBLIC FINANCIAL INTEREST IN POLISH TAX LAW
}

\author{
WITOLD MODZELEWSKI
}

\begin{abstract}
The paper describes the backgrounds and presents critical postulates to the Legislator, which altogether form the indispensable premise, indeed the foundation, for the defense of our country's interests. First, to eliminate the secret lobbying in the law-making process. Every expert must be bound to reveal in public whether he has a conflict of interest, under legal responsibility. Second, all and any links between public authorities and the tax business specializing in "aggressive tax planning" must be severed. Three, an investigation committee ought to be set up, tasked with investigating into all the pathologies identifiable in the regulations development process in respect of VAT as well as the other taxes (excise tax and income tax, in particular), where the losses are no less severe, or even severer, compared to the income gained. So far, the constitutional system of Poland has not opposed the degradation of the establishment, interpretation, and application of substantive tax law - a matter of so high importance for the financial interest of the State.
\end{abstract}

\section{Keywords}

Tax law; public interest; Poland

\section{JEL Classification: D63, H24, K34}

\section{Introduction}

Public financial interest is usually defined intuitively: its content and purpose are for the public levies system to ensure non-reimbursable income sufficient to cover the indispensable and reasonable public spend and debt servicing (if any). In tax-

1 President of the Institute of Tax Studies. Professor of the Faculty of Law and Administration at the University of Warsaw. In 1992-1996 Vice-Minister of Finance responsible for the reconstruction of the Polish tax law system. During his term, tax on goods and services and excise tax, labeling of excise goods, investment reliefs in income taxes, regulations on taxpayers identification were introduced. Academic lecturer at the University of Warsaw, the Warsaw School of Economics and other universities. The Author and Co-author of over a thousand books and articles devoted mainly to taxes and tax law. Tax Advisor and Legal Advisor. Contact email: biuro@isp-modzelewski.pl. 
law terms, the content of public financial interest is strictly defined. Specifically, the provisions of a tax law are compliant with public financial interest whenever:

- substantive tax law (detailed section) proves to be sufficiently fiscally efficient;

- the general section of tax law (substantive and procedural) ensures efficient assessment and enforcement of tax arrears whilst also eliminating tax escape;

- a repressive tax law ensures a proportional system of penalties, with a preventive (deterring) effect.

I will herein refer to the first of these issues. Substantive tax law is concordant with public financial interest only when it proves sufficiently fiscally efficient this being a measurable phenomenon, comparable in time. The annual analytical indicators useable in the assessment of efficiency are the following:

1) the share of the amount of net tax paid ${ }^{2}$ in the total taxed tax bases;

2) the share of the amount of net tax paid in the total sum of tax bases (taxed and exempt from taxation due to tax exemptions and reliefs applied);

3) the share of the total amounts of net tax paid in the estimated amount of due/ output tax (tax loophole);

4) the share of the total amounts of net tax paid in the total balance-sheet revenues from taxpayers (in their entirety);

5) the ratio of the total amounts of net tax paid to the amount of tax arrears due thereto (interest excl.);

6) the share of total refunds in gross proceeds;

7) the ratio of the total amount of net tax paid to the estimated cost of its collection.

The most synthetic indicator is the annual share of the amounts of tax paid in the GDP and the increase/decrease trend in this share. This measure allows comparing the fiscal efficiency of individual taxes in time and in the international scale.

Obviously, the fiscal efficiency of a tax depends not only on the condition of the substantive tax law, since there have appeared (and still are appearing) escapes from taxes with use of apparent or real action, as well as deliberate or unconscious disregard of fiscal obligations. The most useful measure reflecting the tax escapes is the share of the amounts of tax paid in the estimated due (output) tax. 
Substantive tax law established in the financial interest of the State has to maximize the fiscal targets measured with use of analytical (items 1 to 7) as well as synthetic measures. In case the measures applied show a deteriorating profile of the tax, the reasons for this need being identified; in the first place, the provisions in the tax law must be identified which have enabled or facilitated the tax escape, or directly result in a gap-in-the-law. Change in legal regulations is, namely, the simplest and the least expensive means of protecting the State's financial interest. In most contemporary cases of the decreased fiscal efficiency of individual taxes, it is this particular factor that was of decisive or fundamental importance. As it follows, each particular tax ought to be analyzed, on an ongoing basis, in the light of the aforesaid measures, in order to identify the reason behind changes occurring in its fiscal efficiency and formulate de lege ferenda postulates.

\section{Problems of Creating, Applying and Interpreting Tax Law}

The above considerations are related to the assumption that substantive tax law is developed on a bona fide basis, and the legislator is unwaveringly driven by the financial interest of the State. Yet, even a cursory observation of the evolution of the Polish tax law in the last decade challenges this argument, for creating a tax law contrary to the public interest is a known phenomenon, commented on by publicists. In parallel, a depreciation of the materiality of the fiscal purpose of making the tax law, or even a fading of this purpose, has continued over many recent years. The reasons behind the process are rather complex but commonly perceptible; they include:

- an atrophy of the state awareness of the essential part of the political class, who tend to treat power as a trophy enabling to pursue one's private goals;

- lobbying that aims at creating a tax law in the interest of those who are reluctant to pay taxes;

- tax business, including "international" tax business, which contributes to the making of tax provisions in order to make money on them.

In the traditional narrative on the substantive tax law, the belief prevails that such law is formed to satisfy the financial interest of the State. Is it not, however, a matter of an idealized past? In our country, this law is, in its material aspects, "settled" (as simple as that). One can "fix", or "settle", the content of a regulation, its interpretation, or method of application (including no option to apply it). Not being 
inventive, anyone who deals with this field knows it and can quote any number of examples. ${ }^{3}$

What does such "fixing" of instituted law look like, at a closer glance? Let us first take a look at the legislation process. In order to adopt the demanded regulation, it is necessary to use the services of a specialized legislation business, which include the following steps:

- first, a draft of the (set of) regulation(s) or normative act is, obligatorily, compiled by (unknown/unidentified) private legislators;

- next, "free mass media" come into play, criticising the solutions in place and giving arguments in support of the need for a change;

- then, the floor is given to men of authority, who propose "scientific" or "professional" justifications for the proposed alteration;

- at the subsequent stage, the proposed project is stealthily put on the appropriate official's desk - which is, where the legislative process formally begins.

This is followed by a formal legislative procedure, which is fully "transparent" and "clear": the draft needs to be protected against getting "tripped up" by someone, mostly, by accident. Such a scenario is not quite plausible, though, for the procedure in question is pointless (save for rare exceptions to the rule): only the drafts with a formal placet tend to be adopted.

In all fairness, it should be remarked that it has not always been so. Years ago, in the early 1990s, draft pieces of legislation concerning substantive tax law were written in this country by loyal officials under the strict supervision of their superiors of expertise; politicians had some taxation concepts which they ordered their reports to implement, whilst there was virtually no legislative business existing. We have witnessed its rapid development only in the present century, in connection with Poland's entry into the European Union. The business in question has been operating under the patronage of liberals, left- and right-oriented alike.

This is how an essential portion, if not a majority, of (detailed) substantive-tax-law regulations, are made in Poland - not in the financial interest of the State, which

3 This is not a sort of knowledge to be accepted by any of the "opinion-making media" (as they call themselves). When I was recently invited to take part in a discussion on the "domestication" of banks, I repeated the unquestionable argument that all the regulations of the banking law of material importance have been designed by the banks themselves (which none of the disputants opposed). My argument was not quoted in the media, for it exceeded the confines of the correctness "in force". Polish mass media speak in terms of Mr. Balcerowicz's categories, which depict a simple world: there are evil politicians/officials and there are good banks. All this in spite of the fact that all the banks of importance are governed by former or present politicians or former officials. This is what a politician says, twice a Deputy Minister, who has utterly lost the election, together with his political party. 
otherwise should be an obvious thing as far as the financial law is concerned. ${ }^{4}$ This fact, regrettably, affects in an extremely destructive fashion the awareness especially, the legal awareness - of taxpayers who have to subject themselves to the solutions governed by vested interest.

"Fixing" an appropriate interpretation of the regulations is a much easier thing to do. Suffice it to submit a deliberately partitioned set of applications for interpretation, to make the competent authority disoriented. With the "deal" thus "hammered out" a series of favorable views formally approved - the applicant puts them together and then applies again, now for confirmation of the whole "taxpayer-friendly" concept. Everybody knows about it, the issue is debated in public - usually, to no response from the Minister of Finance, for he (whoever is in office) has actually been taking part in these dealings for years now.

The making of legislation can, of course, be influenced in a more sophisticated manner. Thus, one holds a conference - a scholarly one, to be sure - and invites experts (who would surely never make the slightest mention of their own "business" affiliation), "international" counseling business, judges, officials, and journalists. As a result, "representative" views are produced, which (this is for certain) coincidentally have nothing to do with the State's financial interest. The ranks of this business, let us add, have been for years been supplied with herds of civil servants formerly working for the Ministry, which apparently crowns their careers.

All the formal actors of the legislative process leading to the formation of substantive tax law (in its detailed section) - that is, the Ministry of Finance, the Government, the Sejm and the Senate (i.e. the lower and the upper house of the Parliament), and the President of the Republic, only make up a curtain behind which the one who actually governs the process operates. None of these actors are perhaps willing to know what they participate in, or maybe they really are not aware of what is going on. ${ }^{5}$

The tax business has often been an intermediary in the compilation of tax regulations. What I mean is the foreign as well as domestic business, to be sure - the latter being involved in lobbying activities for years. The business has grown fullfledged, capable of earning giant money, unattainable in any other circumstances

4 More importantly, even in public utterances concrete regulations, or even laws, are referred to by their nicknames based on the names of the companies in whose interest the regulation/law has been "settled".

5 I have warned our Dear "All Saints" many a time that any regulations thus fabricated will be to the sheer detriment to public finance: their actual authors act solely in their own interest, in their eagerness to make money taking advantage of the legislator's naivety. My letters were passed by in silence, as a rule - though even more frequently I was given a somewhat vague tint that "there's more money to remain in the taxpayer's pocket", for "the less tax, the better". Such a canonical liberal concept has proved damaging to the Polish fiscal system over the recent ten years or even longer; a concept that has, unfortunately, already appeared somewhere at the background of the new Government whose official idea has been to improve on ("tighten") the tax system, basically supported by their voters. 
and, primarily, has entered political and clerical circles. It prevails in the trade media as well, interpreting the regulations in magazines, awarding prizes to themselves for successes in counseling, and acts as the only expert in tax policies (the "newspaper experts"). Lobbying is, of course, a legal activity and nobody can be punished for it. Tax regulations should be written by politicians observing public interest, whilst no expert should ever find himself in a conflict of interest - such as, for instance when dealing on a daily basis with tax optimization using the "Luxembourg agreements".

We all basically tend to (legitimately) criticize the way the legislative process goes; in tax legislation, one can speak of multiple pathologies appearing. It is not known who compiles drafts which are subsequently adopted by the Sejm, with no verification or afterthought at all. All this takes place in a distorted ambiance of suspicions of lobbying, the omnipotence of nameless officials, and conspiracy of so-called experts who often represent the interest of the tax business. It is high time now to (re)think how to rationalize and heal the process of making substantive tax law - and, primarily, how to try and outline its major non-political principles so as to protect the State's financial interest. Contrary to the appearances, there exist certain specific rules governing the process, although some of them are the emanation of the general principles of reasonable legislation. Analysis of the legislation path of most of the essential tax laws or acts (introducing new taxes or amending existing regulations) leads to describing the process under discussion in the following general terms:

- Most of the substantive or content-related alterations in a draft emerge at the initial stage, in the course of the (not-quite-transparent) "inter-ministerial consultations" which, contrary to the name, extend to an extremely large (and undefined) number of attendees/contributors.

- Clerical opportunism tends to be predominant when it comes to "putting the draft together", according to the rule describable as "submitted by someone - nobody else is against - let us keep it then".

- Any official opinions on the submitted drafts are formal or outright seeming: such opinions appear in excessive numbers and thus are probably read by no-one. The more contradictory they are, the (horror!) "better", which, in objective terms, renders any ex-post control of the process unfeasible.

- The role of anonymous compilers/editors, who give a set of regulations/ law a formal shape (at the working stage and conclusively), is prevalent. Genuine knowledge of taxes and taxation is alien to them, as a rule. While they are not to blame for the latter, given the circumstances of no leading idea present, or purpose of most of the regulations concerned, both a welland ill-constructed "piece of furniture" gets incessantly polished, since the 
"governing rule" says that it is the quality of varnish that counts and matters most.

- Immateriality of tax knowledge (not to be confused with knowledge of taxlaw provisions/regulations) has not bothered anybody over the years: once the draft's Author remains nameless, and there is no-one to embrace the problem in its entirety, there is room open for anybody whoever should like to add or thrown something in, whilst (not infrequently) remarking that s/ he has no knowledge of taxes. In any case, nobody would resolutely stand in defense of his/her proposal, to avoid suspicion of self-interest.

- As a rule, there is no-one to know where the regulations originally came from and how those corruption-generating regulations or those turning into a source of income for the chosen few (those to "reap the harvest") have been added. I have repeatedly endeavored to investigate who on earth has written all these privileges that have led to the fiscal degradation of what is presently the corporate income tax - to no avail, though: the solidarity of the Authors of such projects is, well, "enviable".

- Most of the process's participants are in tacit agreement that they should adopt ostensible solutions: everybody knows that the idea is of no value or will remain a dead letter - one example being the "tax credit" for those starting a business (a game of deception).

Establishment, interpretation, and application of substantive tax law (in its general section) is critical to ruling a democratic country. Almost every aspect of these processes are public by nature: the creation of the law, controlling the taxpayers, decisions issued by Government administration, case-law and judicial decisions. Taxes ought to be formed by those in power, on an exclusive basis; they should be created in the State's financial interest, which is not contrary to the need to protect private interests - obviously, within the confines of the law and in accordance with its purpose. The necessity of particular protection by the employer, the administration, and courts-of-law of taxpayers' private interests has been emphasized for years, it sometimes being ignored that what is essential to taxes if reasonably comprehended - is that public interest is contrary to private interest and that the former takes primacy over the latter. When the public opinion learns that the first twenty-five years of what is referred to as the transition ends up with a high and incessantly growing public debt and decreasing tax income, in spite of an economic growth, the question is worth posing: What is going on around here? Taxes are present in the media on a daily basis, with hundreds of thousands of legal problems being analyzed with deliberation. Since we give so much attention to them and put so much effort in them, why is it going so bad then? When one gets into the details, though, it becomes apparent that something is wrong with it, and our embarrassment is quite an expectable response. Why? Because all this gigantic 
effort to create, interpret and apply taxes is a sort of "the idle running" - or, is merely detrimental to the State's financial interest. The fact that crypto-lobbyists report on draft laws to Sejm committees is no more astonishing to anybody. A worse thing is that creating the law as it does not lead to solving most of the problems which only the public authority may, and indeed should, address. In an attempt to answer why this is all so, I propose the argument that across the crucial 'segments' of wielding fiscal authority - i.e. legislation, the pragmatics of tax administration, and the judicature - we have been dealing, for long years now, with something I describe as the escape from the ruling.

The phenomenon manifests itself as follows:

- Tax legislation tends to create legal regulations or such that directly implement interests quite distant from the State's financial interest, or, deliberately refuses to deal with the issue which otherwise is the declared object of this same regulation. The tax administration practice multiplies its "own" interpretative doctrines, splits hairs, all too often maltreating what the legislator has produced, and thereby only deepening the state of uncertainty and lostness.

- The judicature has become thoroughly unpredictable: they are finding multiple ways to remove problems from themselves and, primarily, pass verdicts that can resolve nothing - as confirmed by the long-known adage which says, "God moves in mysterious ways - and so do courts-of-law."

The actors have come to a peculiar excellence in playing these roles: a weird regulation is soon overgrown with dozens of contradicting views, which are subsequently "cherished" and "developed" in an endless serial of convolutedness and embroilment. The question, "Why it is so?" is a different story, though.

I will hereby try to sketch out a few, rather known, factors. First, in the last dozen-orso years, there is no-one to have built any positive tax doctrine of our State. On the contrary: much has been done to propagate demoralization in this regard. Second, since long ago, there has been no "tax policy" in place in this country, which would have been implemented by political parties and Governments. Politicians are not keen on taxes, considering them a boring topic, or even dangerous to their image. Third, there are no positive benchmarks in place which could be referred to in the everyday practice of ruling tax issues. What the EU practice has contributed to our household (obscure directives, decision-making indolence, contradictory verdicts of EUCJ) is something probably even worse than our domestic "accomplishments". Fourth, the "privatization" of the development of tax regulations that emerge within the magical triangle, officials - lobbyists - experts is death-dealing for the very 
essence of tax law. The latter must be made in public interest, and only politicians can stand in its defense.

\section{Conclusions}

Among the very basic and undisputable obligations of any Polish public authority is to act in the interest of our country, in line with the Constitution of the Republic of Poland. This has not always been so, in a more or less remote past - and not only. The recent toleration of mass-scale taxation avoidance, including value-added tax refund frauds, has given an example of atrophy of the tax system and was, primarily, an instance of violation of the country's constitutional order. Is avoidance of taxation, creation of "optimizing structures", issuance of fictitious invoices for some never-provided services part of civic freedoms? Can the public authorities shun their duty to eradicate such occurrences? As we know, we live under the dictate of a liberal correctness with its predominant view whereby the worse it goes with taxes, the better; for the "smaller", worse-paid and more incompetent state is - well, all the better, as then it "would not be able to hinder the unrestrained development of entrepreneurship". A liberal mindset clearly would not adopt the argument that there would be nobody to pay those equally low and simple taxes when the state is weak, and when an unrestrained latitude might (and, certainly would) be an advantage for bandits and thieves (including those wearing expensive suits) as well as for foreign inimical countries ("foreign" would normally mean "inimical" in this regard) to destroy ours, and bleed it white. Hence, I should like to put forth (as many as) three critical postulates to the Legislator, which altogether form the indispensable premise, indeed the foundation, for defense of our country's interests:

- Eliminate the secret lobbying in the lawmaking process. Every expert must be bound to reveal in public whether s/he has a conflict of interest, under legal responsibility.

- All and any links between public authorities and the tax business specializing in "aggressive tax planning" must be severed.

- An investigation committee ought to be set up, tasked with investigating into all the pathologies identifiable in the regulations development process in respect of VAT as well as the other taxes (excise tax and income tax, in particular), where the losses are no less severe, or even severer, compared to the income gained.

So far, the constitutional system of Poland has not opposed the degradation of the establishment, interpretation, and application of substantive tax law - a matter of so high importance for the financial interest of the State. 